\title{
THE UNITED NATIONS FROM A EUROPEAN POINT OF VIEW
}

\author{
WILLIAM E. RAPPARD $\uparrow$
}

THE Charter of the United Nations, like any national constitution or international treaty, may be considered from a variety of viewpoints.

It is, on the one hand, a legal enactment. As such, it may be impartially analyzed by lawyers all over the world, quite irrespective of their nationality. Its victorious signatories and their defeated enemies, as well as the small band of neutral onlookers, may all study it with a view. to understanding its meaning and to interpreting its provisions in the light of the probable intentions of its drafters. If we assume them to be equally well-informed, equally well-trained, equally careful in their analyses, and gifted with equal acumen, there is no reason why they should not all, whatever their language, race, or creed, reach the same or at least equivalent conclusions.

On the other hand, the principles underlying the Charter and their practical application are also historical facts. As such their origin, their political significance, and their ethical implications will be very differently assessed in different parts of the world. Each state, each region, each continent, each class of society and each individual citizen everywhere, will view them in the light of its or his own interests, prejudices and general philosophy. Therefore, it is to be expected that there will be no unanimity of outlook on the institution of the United Nations and its Charter.

Both methods of approach, the strictly juridical and the socio-political, are useful and legitimate, each for its own purpose. But even for the jurist, who as lawyer, as consultant, or as judge may be called upon to interpret the Charter, it is important to understand the position taken with regard to it in lands other than his own.

The following considerations are submitted by an inhabitant of Geneva, the seat of the late League of Nations, who has for many years been interested and engaged in various forms of international activity. As a citizen of neutral Switzerland, however, he can lay claim to no other information concerning the United Nations and its Charter than that which he has been able to gain from a perusal of the published documents, supplemented by personal observations and conversations in London last autumn and this winter.

The European viewpoint from which he considers the United Nations is, therefore, that of an outsider, of a keenly interested but foreign well-wisher of the new organization. His natural bias, in so far as his

$\dagger$ Professor at the University of Geneva; director of the Graduate Institute of International Studies; former member of the Permanent Mandates Commission and of the Swiss Delegation to the Assembly of the League of Nations; author of various publications in the field of international relations. 
deliberate efforts have not sufficed to free him of it, is that of a citizen of a small country in the heart of the Old World. It may be noted that this country attributes its persistent independence throughout the centuries to its peculiar Alpine situation and to the constant practice of armed neutrality which it had not even abandoned as a member of the League of Nations.

It is not with Switzerland, however, but with Europe as a whole that we are here concerned.

In order fully to understand Europe's general attitude towards the United Nations, four main facts must be considered. The first is that the new organization for the maintenance of peace was, like the old, born of a war which was essentially European both in its origins and in its main battlefields. The second is that the Charter is essentially an American document in its inspiration and in its formulation. The third fact is that this American product of a European war was dralted before the end of hostilities by the victorious belligerents alone, without any consultation with either the neutrals or the defeated. The fourth and final fact is largely the result of the three former: as the war was won mainly through the exertions of the three major povers, of which one was American, the second half-Asiatic, and the third maritime and insular; as, furthermore, at the time of the drafting of the Charter, the continent of Europe was almost completely divided between defeated belligerents, occupied or recently liberated victors, and neutrals, Europe feels, if not totally excluded from the new organization, at least very much under-represented on it and therefore much less intimate with it than it was with the League of Nations.

This study is to be devoted to the examination of these four fundamental facts.

\section{The Untted Nations as a Product of European Belligerency}

Since the end of the Napoleonic wars a trend towards the establishment of international institutions is discernible in European and indeed in world history. The latter half of the nineteenth century witnessed the multiplication of international conferences and congresses and the creation of a variety of technical international bureaus and unions. With the Hague Conferences about the beginning of the twentieth century, the movement toward international institutions progressed from the discussion and settlement of technical questions to the political sphere. It was only during and after the first Morld War, however, that the organization of international society into a true community for the maintenance of peace became a political issue of the first importance.

The first World War had been essentially European in origin and in scope, and the first League of Nations had been essentially American 
in authorship and in design. Had it not been for aggressive AustroGerman imperialism, the war would not have broken out in August 1914. And had it not been for Anglo-Saxon, particularly American, and still more particularly for Wilsonian, idealism, the war would presumably have ended without the creation of a League of Nations.

In both these respects history was to repeat itself a generation later. Without Italian fascism and German national socialism, war would not have broken out in the nineteen-thirties, and without Anglo-Saxon and particularly American, and still more particularly Rooseveltian idealism, the second World War also would presumably have ended without the transformation of the belligerent United Nations into an organization for the defense of peace and security.

Twice in a lifetime suicidal Europe plunged into war. Twice in a lifetime it escaped annihilation or serfdom by the reluctant but tritum. phant intervention of the United States. Twice in a lifetime the experience of abhorred but unavoidable military action led American statesmanship to seek relief from its repetition by the creation of an organization for the maintenance of peace.

In view of this sequence of events, no one can deny that the League of Nations and the United Nations were both born of European belligerency. In spite of the unavoidable over-simplification of this brief summary, that conclusion is almost axiomatic.

\section{The United Nations as a Product of American Statecraft}

It is clear that the United States was the prime mover in creating the United Nations. It was after much American preparation that, on the invitation of America, the Dumbarton Oaks Conference met at the American capital. It was as a result of American initiative and under American chairmanship that the Charter was drafted on the West Coast of America. And it was in deference to the late American President that the United Nations assumed its American name. Likewise were all the allied and subordinate agencies of international cooperation of American origin, as the recital of their birthplaces in Hot Springs, Atlantic City, and Bretton Woods suffices to recall.

It is for three main reasons, ethical, political, and geographic, as I see it, that it has fallen to the United States more than to any other country to draw the pacific conclusions of two successive world wars of European origin.

The first of these reasons is perhaps not the most apparent. But it is, I believe, the most fundamental. Doubtless it would be absurd and most unhistoric to see in the American people a nation of pacifists. In the destiny of few countries has armed force been more frequently resorted to. Even if we leave aside the early Indian wars, without which this continent might never have become a white man's land, it cannot 
be forgotten that American independence was achieved and, less than a century later, American unity saved, by military operations. The scale of these operations, when related to the contemporary size and resources of the country, was considerable. Their violence furthermore shows that the American people when aroused lack neither the courage to undertake nor the tenacity to carry to their bitter end, wars no less bloody than those which have devastated the rest of the world. Nor can it be claimed that Americans will fight only when attacked, as the Mexican and Spanish wars suffice to show.

It cannot, on the other hand, be maintained that Americans have ever enjoyed a monopoly of pacific sentiment and of constructive antiwar imagination. Europe had her Emeric Cruce, her Grotius, her Abbé de Saint Pierre, her Kant and her Bertha von Suttner both before and after America had her TWilliam Penn.

However, in spite of America's belligerent past and Europe's pacifist tradition it is doubtful if there is any large country in which the hatred of war is more deep-rooted and universal than in the United States.

The second reason for the preponderant part the United States has taken in the organization of peace in the twentieth century is undoubtedly to be found in its political importance in the contemporary world. Although this factor is too obvious to call for comment, I wonder if it is not more fully realized in all its implications in the Old World than in the New. The very numbers, wealth, and general enlightenment of the American people have siven rise to internal problems of such gigantic magnitude that they tend to distract public attention in the United States from international considerations. It is a supremely important circumstance that, of the two most powerful members of the family of nations today, the United States is both the more powerful and the more liberal.

Geography, the third factor accounting for the American sponsorship of the League of Nations and especially of the United Nations, has, as I see it, operated in two distinct ways. On the one hand, being far removed from the European birthplace of the two Morld Wars, the United States was drawn into them against its will, and in spite of its instinctive urge to remain aloof. On the other hand, its territory, being neither invaded nor even placed under the direct threat of invasion, seemed predestined to offer hospitality to the efforts of all organizers of peace.

The latter result of geography is the more obvious, but the former is perhaps the more significant. For all civilized nations war is a curse. But in addition, to the Americans, who had no territorial or commercial advantage to gain from the defeat of the aggressor, war would appear as an irritatingly unnecessary and possibly avoidable foreign nuisance.

In their reaction to invasion and to its threat, the Poles, the Norwegians, the Dutch, the Belgians, the French, and even the British 
naturally hated the Germans, as the Greeks hated the Italians and the Chinese the Japanese. For all these victims of aggression, the hatred of the aggressor was naturally so acute and the national emergency so compelling, that the mind, the soul, and the will of the attacked nations were absorbed and exhausted in responding to both. In America, on the other hand, while disgust and contempt for the wanton disturbers of the peace were perhaps equally universal, there naturally remained more freedom of reflection on the general course of events and more room for the abhorrence not only of the war makers, but of war itself. Moreover, as an assault on liberty itself, and therefore ultimately as a menace to the American way of life, the aggression of autocracy provoked a reaction which did not spend itself on the assailant but turned on all those traditional institutions and circumstances which made war possible.

Thus the United States in 1914, 1915, 1916 and again in 1939, 1940, and 1941 launched its offensive against war itself. And this offensive was carried through even after the United States had been obliged by events to renounce its traditional neutrality. Is it not probable that if America had been invaded in 1914 and in 1939, as were her later allies, the immediate neighbors of Germany, America would not have taken the direction of the crusade for peace as unequivocally as she did in promoting first the League of Nations and then the United Nations?

\section{The United Natrons as a Product of the Alliance AGAINST THE AXIS}

In order to understand the origins of the United Nations as they appear to Europeans today, one must always remember that the new organization came into being as the result of a war which broke out in the Old World and of a peace effort which was initiated in the New. And in order to understand the San Francisco Charter, one should ever bear in mind that it was drafted exclusively by, and primarily for, the Allies themselves, at a moment when hostilities had not yet been terminated. It was therefore adopted at a time when the rest of the world, and particularly Europe, was divided between two execrated and largely defeated foes, and a small band of neutrals, some of whom were very suspect and all of whom were negligible.

The new organization was, in the words of the Moscow Declaration of October 30, 1943, to constitute "a system of general security." At Dumbarton Oaks it was decided on October 7, 1944, that one of its purposes was to "develop friendly relations among nations" and "to. strengthen universal peace." Membership in the United Nations is furthermore, under Article 4 of the Charter of June 26,1945, open to all "peace-loving nations." In spite of these and several other similar declarations which could be quoted to show the all-embracing ambitions. 
of the United Nations, the fact remains that the new peace organization, like the old, owed its foundation to rictorious belligerents, but that, unlike the old, it was founded during a war and without consultation with any others. It is therefore not surprising to see it suggested, without apparent irony, "that the best definition of a 'peace-loving' state is one that declared war on one or more of the Axis povers." 1

This belligerent origin of the Charter explains some of its most characteristic features. The first is that to which allusion has just been made. It is as natural that belligerent allies, conferring together in the course of a war, should publicly profess complete confidence in each other, as that they should hesitate to extend such confidence to any outside their own ranks. That is why the authors of the Charter were bound to assume that all the United Nations were by definition "peaceloving" and that they alone were competent to judge of the sentiments and policies of all the other states.

The second consequence of the belligerent origin of the new organization is its hierarchic structure and the authoritarian and militant spirit which animates the most significant provisions of its Charter.

On the field of battle there can be no equality of nations. That is why the San Francisco Charter, though it speaks much of the "sovereign equality of states," violates that principle to a degree unlnown in all previous annals of international law. It maintains and reinforces the privileged position of the Great Powers as permanent and unelected members of the Security Council, much as the Geneva Covenant had done before, but it goes appreciably further in this direction in setting up two distinct sets of rights and duties. According to the Charter, there is one law for the strong and quite another for the weak. There is inequality in laying down and in enforcing the law, as is indeed natural among the most unequal members of the international community; but there is also a complete and flagrant denial of the much more fundamental principle of equality before the law. While the mighty are collectively assured of almost unlimited authority over the weal, and individually assured of almost unlimited impunity in case of violation of their pacific covenants, the latter are denied the right even to be consulted in certain matters of peace and war which, on account of their very weakness, may be much more vital to them than to their stronger neighbors.

That such provisions should have been proposed by the Great Powers, who are the real authors of the Charter, is perhaps less astonishing than that they should have been concurred in by their feebler allies. Both are to be explained solely by the belligerent composition of the San Francisco Conference and by the fact that it met before the return of peace.

1. Goodrich and Haxibro, The Chubter of The United Nations: Cosureisatx And Docusients (1946) SO. 
The same may be said of the rules laid down by the United Nations to govern the conduct of the rest of mankind. Under Article 2 of the Charter it is provided that "the Organization shall ensure that states which are not Members of the United Nations act in accordance with" principles affirmed by the United Nations "so far as may be necessary for the maintenance of international peace and security." Such a rule is, of course, incompatible with the "equal rights . . . of nations large and small" affirmed in the Preamble of the Charter and with the "respect for the principle of equal rights and self-determination of peoples" proclaimed in Article 11, and is contrary to past international usage in times of peace. But as neutral states have recently been reminded to their detriment, it has often been applied in times of war. If we refer to it here, it is to show how the new international code conceived in San Francisco tends to encourage in times of peace indulgence in imperious habits acquired by belligerents in the bitter experience of war. This is due not solely, to be sure, to the contagious example of those dictatorial states which the nations assembled at San Francisco were united to defeat, but mainly to the fact that they were themselves legislating for peace under the stress of the war they had not yet fully won.

Thus, the double assertion of authority by the United Nations as a whole over non-member states and by the Security Council over the minor member states strikes me as an expression of the war spirit which animated the San Francisco Conference. Such an assertion of authority, it may be argued, is required for the maintenance of world peace. Perhaps. But whereas the assumption of authority by the victorious allies over the whole international community, and by the Great Powers over the small, may be held to make for world order, the refusal to grant the United Nations any true authority over the Great Powers themselves assuredly makes for world anarchy. And that also I regard as a symptom of the spirit prevailing at San Francisco.

In times of war, might undoubtedly takes precedence over right. Whence the strength of the Charter as a weapon for the strong. In the long run, however, peace can be maintained only by the subordination of might to right. Whence its inadequacy as a shield for the weak.

When compared with the Covenant of the League of Nations, the Charter affords the international community a much greater measure of protection against minor disturbances. But while making far greater demands upon the independence of the small states, it promises them no effective security against the only real danger to which they are exposed, namely against the possible aggressive designs of the great.

That also can be explained only by the belligerent circumstances under which the Charter was drafted. Arrayed together in a common victorious struggle against a common aggressor, the United Nations were ill prepared to consider any threat other than that which had led 
to their alliance, and they were disinclined to conceive of the treasonable possibility of any armed conflict among themselves. Moreover, for the small states at San Francisco to have sought more effective protection against the great would have been to question the loyalty of their leaders, inasmuch as it was understood that no other Great Powers were to survive the struggle in which the United Nations were collectively engaged.

The belligerent origin of the Charter also explains another of its characteristics, namely its extreme discretion in the matter of international disarmament. After the first World War such disarmament was looked upon both as the price to be paid for, and still more as the great prize to be collected after, the true organization of peace. During the final stages of the second World War such an aim was looked upon as Utopian or even as undesirable. How could it have been othervise when the disarmament of "the peace-loving nations" had almost led to their defeat at the hands of the aggressors and when, moreover, the principal victors themselves were as uncertain about their respective ambitions as they were conscious of their grave divergencies of outlools?

One last feature of the Charter of the United Nations should be noted here, namely that of its relations to the Covenant of the League of Nations. As we have seen, the Charter had a double origin. It was born of a war which the Covenant had failed to prevent and of the action of America which had repudiated the Covenant. It is therefore not surprising that the San Franciscan authors of the Charter were more inclined to deprecate the work of their Generese predecessors than to imitate it. However, as both documents are attempts to solve what is essentially the same problem, as the general sentiment about national sovereignty and international security had undergone no fundamental change, as the Covenant was the expression of much political wisdom, and as the experience gained by the League was not lost upon its often well-informed but none too generous successors, they were on many points led to display their passion for reform by a change of vocabulary more than by any substantive revolution. Thus the Assembly of the League became the General Assembly of the United Nations; the old Council the new Security Council and the Social and Economic Council; the former Permanent Court of International Justice the International Court of Justice; so, also, a novel, much more ambitious but perhaps less promising system of International Trusteeship was substituted for the discarded Mandates System. Was it not, at least in part, also for similar reasons that Westchester County was preferred to Geneva?

This last change, however, also has a much deeper significance. In 1919, Geneva became the seat of the League largely thanks to American influence. President Wilson and the majority of the drafters of the Covenant were of opinion that peace should be built on the founda- 
tions of justice, that impartiality was a condition of justice, and that a neutral country offered the greatest guarantee for the impartial consideration of international problems. In 1945 the prevailing atmosphere among the leading victors was very different. What, in the face of the unspeakable crimes of the aggressors, was justice, if not revenge? What, in view of the tortures endured by their victims, and of the apparent indifference displayed by the neutrals, was professed impartiality, if not weakness or even complacency? Why, therefore, revert to the errors of the past and select for the preparation of a better future a neutral rather than a belligerent site?

While Geneva was the logical choice for the seat of a pacific League, or, better, Society of Nations, some city of the principal victorious state was a logical choice for the seat of an organization which had chosen to carry over into peace the very name which its founders and sole members had glorified on the fields of battle. Furthermore, New York is as symbolic of the New World as Geneva was of the Old. This leads us to the consideration of our fourth and last point.

\section{The United Nations as a Non-European Organization}

Of the 51 states which have signed the San Francisco Charter and thus become original members of the United Nations, 22 are situated in the American Hemisphere, 15 in Europe, 10 in Asia and Australasia, and 4 in Africa.

Such statistics, which taken in themselves present very little interest, suffice to show how feebly Europe, which before the second World War counted no less than thirty sovereign states, is represented in the new organization. From the European viewpoint, these statistics fail, however, to give the complete picture of this under-representation.

Of the fifteen European states whose delegates sit in the General Assembly, three belong to the Soviet Union and at least three others to countries which are hardly in a position to pursue a foreign policy independent of Moscow. That leaves nine European states, including Greece and Turkey, which partake of that civilization which is commonly called Western. Of these nine, all but two, having been overrun and occupied by the enemy in the course of the war were, in the preparatory stages of the Charter, represented by governments-in-exile. Of those two, one is Turkey and the other the United Kingdom. The former is considerably more than half Asiatic, and the other is not a part of continental Europe. Moreover, as the metropolis of a far-flung empire, Great Britain has interests in all parts of the world and can therefore not be regarded as a purely European state.

The conclusion suggested by this brief review is obvious. Europe was almost totally absent from the councils of the Great Powers which laid the foundations of the United Nations. At San Francisco, Europe 
was only very partially represented by a limited number of governments whose international authority was seriously impaired by the uncertain hold they had on their own only recently liberated peoples. Even today Europe, once the proud master and creditor of the civilized world, is reduced to the humble position of a prostrate, self-mutilated and heavily indebted servant. Such is the price of the two World Wars of which she was the responsible author, the main theatre, and the principal victim.

No wonder, then, that over half of Europe is alien to the United Nations and that even those European states which have been admitted to the temple of peace erected by others than themselves find it hard to feel truly at home within its unfinished and none too hospitable walls.

It would be an error, however, to deduce that Europe, because largely alien to and excluded from the United Nations, harbors any hostile sentiments toward its founders and its members or anything but the most friendly interest in its aims and purposes. Almost all the states which have not yet been invited or eren allowed to sign the Charter are anxious to do so without delay and without reservations. For all the defeated states it would be an impatiently awaited rehabilitation. For the neutrals it would be a liberation from their moral and political isolation and a most welcome opportunity to join in a collective effort for the reconstruction of Europe and for the reestablishment of normal relations of confident cooperation with the rest of civilized mankind.

This general willingness and well-nigh universal desire to adhere to the Charter does not indicate that its provisions meet with equal approval everywhere. It would, I believe, be nearer the truth to say that the nations of Europe aspire to join the United Nations in spite of the Charter rather than because of it. It is the desire to create new political bonds of cooperation and, for the defeated, to sever or loosen old bonds of hostility and vassalage, that impels Europe to seek admission to the international organization.

The Charter itself, in so far as there can be said to be any opinion on the subject, is generally held to be inferior to the Covenant in that it makes far greater demands on the independence of member states while promising them far less security.

'In order to understand this statement, one must remember that the European viewpoint on the Charter is necessarily that of the small states which constitute the Old World today, and that the new organization, while a legal paradise for the Great Powers, seems to be a legal jail for the minor countries.

One of the features which clearly distinguishes the United Nations from the League is that it is founded on the principles of coercion rather than those of persuasion and emulation. Another, as we have seen, is that in spite of the repeated references in the Charter to the "sovereign 
equality" of its signatories, it in reality creates two entirely different classes of members: a minority of five Great Powers who have the right to command but not the duty to obey, and a majority of small states who are legally bound to carry out the instructions of the Security Council, over which they can have but a very limited influence. Without attempting here fully to substantiate this view, which is hardly debatable, I shall be content to quote the three following most significant provisions of the Charter:

Article 24, Paragraph 1, reads:

"In order to ensure prompt and effective action by the United $\mathrm{Na}$ tions, its Members confer on the Security Council primary responsibility for the maintenance of international peace and security, and agree that in carrying out its duties under this responsibility the Security Council acts on their behalf."

Article 25 reads:

"The Members of the United Nations agree to accept and carry out the decisions of the Security Council in accordance with the present Charter."

Articles 24 and 25 achieve the complete subordination of the small states to the Security Council. The five permanent members, on the other hand, are insured complete independence by the first sentence of Paragraph 3 of Article 27:

"Decisions of the Security Council on all other matters [other than procedural] shall be made by an affirmative vote of seven members, including the concurring votes of the permanent members. . . ."

All these provisions expressly create an unequivocal duty to obey the orders of the Security Council, a duty, that is, of all states except the Five Great Powers, whose right of veto confers upon each of them exceptional influence over the Security Council and an equally exceptional independence of it.

If and when unanimous, these Powers are practically the masters of the Security Council and thereby of the United Nations, since with the concurrence of two small states they may dictate its policy. If and when they are not unanimous, on the other hand, the Security Council and therefore the United Nations are powerless as agents for the enforcement of peace.

Inasmuch as the only real danger to the peace of the world is a war willed or approved by at least one Great Power, the security promised the signatories of the Charter is as precarious and illusory, as are direct and far-reaching the inroads it entails on their national sovereignty 
In fact, the freedom of all the small states is contingent upon the disunity of the great, whereas their security is equally contingent upon the unity of the Great Powers.

As a means of reconciling national freedom and international security-the supreme problem of world politics-the Charter therefore can hardly be hailed as a promising Gospel of salvation. It possesses, however, one great superiority over the Covenant, namely that it has proved acceptable to the American Senate. This practical superiority, which may at least in part be due to its theoretical inferiority, is such that it has changed the whole aspect of the political world.

The League of Nations, whose members were bound together by the ties of a Covenant which demanded less sacrifice of national sovereignty of its minor signatories and which promised greater security to all, proved impotent largely because of the abstention of the United States. The United Nations, assured of the support of all the Great Powers, thanks to the right of veto which its Charter had granted them, is today the great and almost the sole hope of humanity. It is for that reason that Europeans, well-nigh unanimous in criticizing its constitution, are well-nigh unanimous also in seeking admission to its ranks.

\section{Conclusion}

Having from a European viewpoint cast a glance at the origin and present status of the United Nations, I feel impelled in a final word to consider the future of the new organization.

We have seen that, although this organization was born of a war that originated on the continent of Europe, the states of the Old World had had very little to do with its construction. We have seen also that even today the continent of Europe is greatly under-represented in the United Nations. I do not believe this state of affairs will continue indefinitely. Europe is anxious to become a full member of the new organization and is prepared, for that purpose, to overcome or at least temporarily to overlook the misgivings inspired by certain features of the Charter. If the United Nations is to succeed in the efforts, initiated on the fields of battle and laboriously pursued since in the sphere of diplomacy, to establish, maintain and consolidate peace, the active cooperation of Europe would seem indispensable. This is so, not in spite of the fact that that benighted continent has been a hotbed of wars in the past, but for that very reason. The defeat of the guilty aggressors and the occupation by the victors of their conquered territory was and is a necessary condition for the restoration of peace. But surely they cannot be looked upon as a sufficient condition for the maintenance of peace. As for the neutrals, their exclusion from the ranks of the United Nations was no less logical than was that of the defeated foes during the period of belligerency, and it will remain so 
until the treaties that are to put an end to the present state of war come into force.

Once peace has been made, however, the continued exclusion of any truly peace-loving nation from the ranks of those who have set themselves the task of protecting mankind against a renewal of the horrors of war would surely appear unjustified in its motives and unfortunate in its consequences.

The most ardent peace-loving citizens of the world, within as without the United Nations, are all equally critical of certain fundamental characteristics of its Charter. But all are convinced that even if imperfect, this Charter is certainly better than none, and that they must exert all their efforts towards improvement, enlargement and reform of the new organization. 